\title{
Colorectal Cancer in Pregnant Woman
}

\author{
Predescu Dragos* and Marius Boeriu \\ Clinic of Surgery, St. Mary Hospital, University of Medicine and Pharmacy Carol Davila, Romania
}

*Corresponding author: Predescu Dragos, Associate Professor, Clinic of Surgery, St.Mary Hospital, University of Medicine

and Pharmacy Carol Davila, Romania

ARTICLE INFO

Received: May 08, 2020

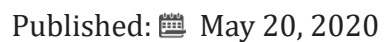

Citation: Predescu D, Marius B. Colorectal Cancer in Pregnant Woman. Biomed J Sci \& Tech Res 27(5)-2020. BJSTR. MS.ID.004553.

Abbreviations: CRC: Colorectal Cancer; CIN: Chromosomal Instability; MSI: Microsatellite Instability; HNPCC: Hereditary Non-Polyposis Colon Cancer; FAP: Familial Adenomatous Polyposis; LS: Lynch Syndrome; PgRs: Progesterone; Ers: Estrogen; IBD: Inflammatory Bowel Disease; UC: Ulcerative Colitis; CD: Crohn Disease; FOBT: Fecal Occult Blood Testing; UICC: Union for International Cancer Control

\section{Abstract}

Colorectal cancer (CRC) is one of the most common human malignancies, affecting one of 20 persons in areas with high socio-economic standard but cases of digestive cancers during pregnancy are rare. From an etiological point of view, CRC represents an entity induced on the one hand by environmental factors and on the other hand by genetic factors or, not rarely, by their combination. The difficulty of diagnosing digestive cancers in pregnancy is the consequence of a symptomatology often masked by signs and symptoms that can be attributed to pregnancy. Essential in terms of assessing the staging of TNM in CRC, CT remains the subject of numerous debates. Over the last 40 years CT has been contraindicated in pregnant women due to teratogenic and carcinogenic effects on the fetus. Pregnancy MRI method is preferable to any other method of investigation that uses ionizing radiation. The CRC's treatment plan must take into account the interests of two people, the mother and the fetus, so that the "interest" of one does not affect the other, respecting an axiom: treatment as soon as possible for the mother after a birth as soon as possible for the fetus. Colorectal neoplasia is generally a predominantly surgical pathology at the time of disease discovery, especially in conditions of a major complication that leaves no time for a therapeutic alternative (obstruction, perforation, significant bleeding). A chemotherapy-type oncology protocol option is preferred for cases with advanced, metastatic neoplasms.

Keywords: Colorectal Cancer; Pregnancy; Diagnosis \& Treatment

\section{Introduction}

Cases of digestive cancers during pregnancy are rare, their reporting being sporadic. Because nowadays the pregnancy often occurs at ages between 30-39 (even between 40-49 years old), it could explain the increasing frequency association of cancers and pregnancy. Miscellaneous population trials [1-5] notes in the last 3-4 decades an explosive growth of some digestive neoplasms, especially by involving of some age groups from the fertile period of the woman between 15-49 years. By analogy with breast cancers, digestive cancers in pregnancy are defined as cancers diagnosed during pregnancy and in the first year postpartum. From the multitude of digestive visceral sites, the most frequent neoplasms appear to be the stomach, colon and rectum, only in exceptional cases liver and pancreatic cancers. Also, paraclinical evaluation of these patients is difficult, as the pregnancy trimester is an important indicator of the opportunity of a certain investigation. Precaution related to fetal involvement in the indication of invasive exploration (imaging, endoscopic, etc.) also delays the diagnosis. That is why digestive cancers are diagnosed in pregnancy in advanced stages, usually in the complication phase - occlusion, hemorrhage, perforation or cachexia. The diagnostic and treatment protocols applied to the non-pregnant patient are not similar to those in pregnancy, most often a multidisciplinary approach, involving the association of medical-obstetrician-surgeon-gastro-enterologistpediatric neonatologist-psychologist specialized in oncology, together with the patient and his family will be able to define the correct and balanced approach of the optimal therapeutic plan.

\section{Epidemiology}

Colorectal cancer (CRC) is one of the most common neoplasms and the third leading cause of cancer death. Regarding the incidence of neoplasms in women in general, CRC ranks fourth, after breast, cervical and lung cancer. Cancer mortality in women is attributed, in order of frequency: breast, lung, colorectal and cervical cancers. Overall CRC incidence data shows a modest decrease since the 1980s in industrialized countries and a slow but steady growth in 
poorly developed countries (e.g in the USA since 1998 the incidence of CRC in women has decreased by about $2.2 \%$ per year) [6,7]. This decrease is essentially attributed to the CRC screening techniques $[8,9]$. There was no specific incidence of CRC in pregnant women compared to that in the general population. Consequently, the incidence of CRC in fertile women is consistent with that of CRC in the general female population for decades of appropriate age
( $20-29, ` 30-39$ and `40-49 years old) [10,11]. In the US female population covering the three decades above, it was noted that, in contradiction with the decreasing level of CRC incidence, the statistical data shows a constant growth of CRC of $1.6 \%$ per year since 1992 (Figure 1), especially among the non-Hispanic white population $[12,13]$.

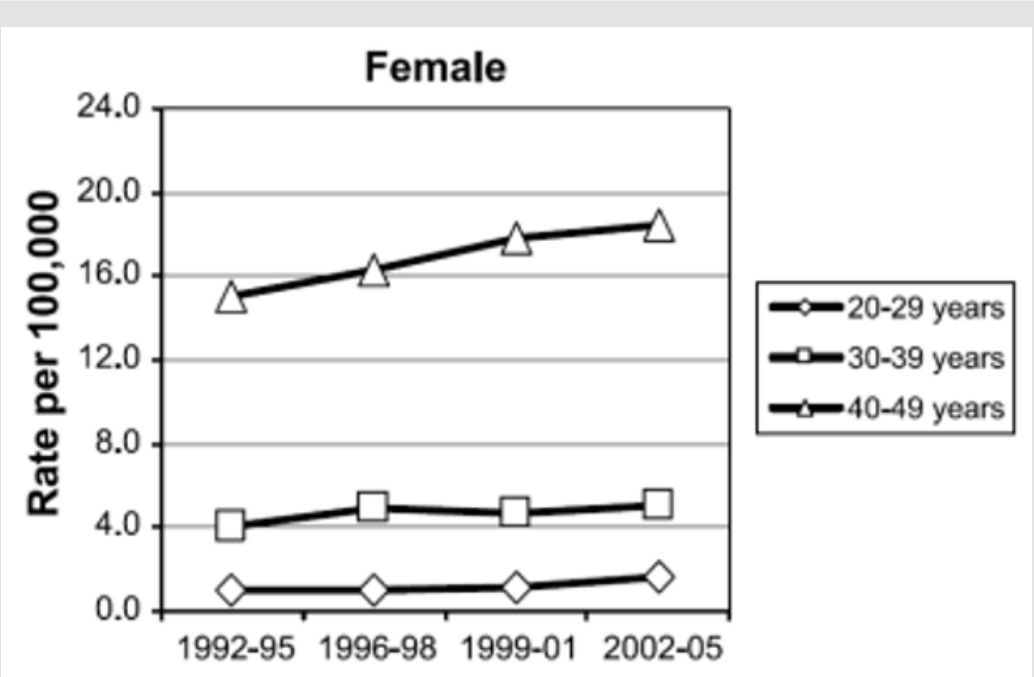

Figure 1: The evolution of CRC incidence in the 20-49 decades. There has been a steady annual growth since1992 (Rebecca L. Siegel) [13].

The first 245 cases were reported between 1842-1995, and between 1996-2004 30 new cases are reported, which almost doubles the incidence of CRC in pregnant women [14-17]. In the unitary group of patients, in the three decades of age, the peak of the incidence appears in the patients of 31 years old. A particular feature of colo-rectal neoplasia in pregnant women compared to the general population is the tumor site. Thus, if in the general population the rectum comprises about $25-30 \%$ of the total CRC, in the case of pregnancy there is a counterbalance, the subperitoneal rectum being interested in most cases [18] (about 85\%). This atypical behavior raises questions about the etiology of neoplasia. Firstly, a different biological behavior of CRC tumors during pregnancy is suggested. Most likely, however, the cause is the discovery of the tumor much easier at routine gynecological control during pregnancy, either due to the accentuation of the symptoms by the tumor growth together with the compression on the rectum in pregnancy.

\section{Etiology}

\section{Environmental and Genetic Factors}

From an etiological point of view, CRC represents an entity induced on the one hand by environmental factors and on the other hand by genetic factors or, not rarely, by their combination. From the genetic perspective, based on the causes involved in the emergence of CRC, there are three major types: sporadic CRC (60-70\%), family CRC (30-40\%), hereditary CRC (genetic diseases $4-6 \%$ ] [19]. Sporadic CRC is rarely encountered under the age of 50.
As a result, the cases reported in literature of pregnancy associated with CRC meet the conditions of family CRC, respectively genetic. However, in sporadic CRC encountered in pregnant women, similar to the general population, we find two mechanisms of genomic instability:

i) Chromosomal instability (CIN), consequence of alteration of genetic material, resulting in inactivation of tumor suppressor genes (ex. TP 53, APC) or activation of oncogenes (Ki-ras) in about $80-98 \%$ of cases [20-23].

ii) Microsatellite instability (MSI), without knowing the genes involved (10\% of cases) [24,25].

Family type associates increased risk of genitors developing CRC (doubles if first-degree relatives develop CRC, especially under the age of 50), while the genetic type associates syndromes known for genetic material abnormalities: HNPCC (Hereditary Non-Polyposis Colon Cancer or Lynch syndrome), FAP (Familial Adenomatous Polyposis), AFAP (Attenuated Familial Adenomatous Polyposis), gene mutation APCI 1307K, Peutz-Jehger's Syndrome, MAP (MYH associated Polyposis), Juvenile Polyposis, Hereditary Polyposis. The identification of the cause that has the effect of the occurrence of the primordial-etiological mutation in the CRC is possible in less than $6 \%$ of cases $[26,27]$. Recent studies [27] have succeeded in characterizing and defining the malfunction of genes involved in CRC etiology in three main classes: suppressor genes (APC, AXIN2, TP53, STK11,PTEN, BMPR1A, SMAD4) oncogenes (KIT, PDGFRA), 
DNA repair genes (MLH1, MYH, BLM). Extremely interesting is the presence of some primary mutations as etiological induction factors for CRC, with the title of mutations, called de novo mutations. The various syndromes (FAP, JPS, Peutz-Jeghers, Cowden, BannayanRiley-Ruvalcaba) have high rates of de novo mutations (25-30\%) [28-30], while LS (Lynch syndrome) associates de novo mutations in MMR at a reduced frequency (0,9-5\%) [31-33].

\section{The Influences of Steroid Receptors}

The hypothesis of the involvement of progesterone (PgRs) and estrogen (Ers) receptors in CRC pathogenesis in pregnant women is extremely interesting. It was found [34-36] that at approx. 20-54\% of CRC reports the presence of Ers [37-39], as other authors identify PgRs in about $42.8 \%$ of cases. It is thus suggested that there is a link between high levels of estrogen and progesterone in pregnancy and the stimulation of CRC proliferation. A second consequence would be the discovery of advanced stage neoplasia, due to the high titres of sex hormones. Cox-2 enzyme. also find in pregnant women the essential role of the Cox- 2 enzyme and derivatives in the early stages of pregnancy (ovulation, fertilization, implantation, and decidualisation) but also in the other stages of pregnancy. Because high levels of Cox- 2 are encountered in CRC, in was made a hypothesis of an interrelation between the two phenomena. In addition to genetic involvement, other etiological mechanisms of CRC, environmental or individual, behavioral are incriminated [4044].

\section{Obesity}

It is a major risk factor especially for hormone-active women in the pre-menopausal period compared to the post-menopausal one. Because the rate of obesity cases has seen a spectacular increase in the last three decades in the industrialized countries [45-47], the causal-effect link is defined in increasing the incidence of CRC at an increasingly young age. The mechanism by which obesity induces tumor development, respectively the latency period between aggression and tumor onset, remains unclear. The corroboration of type 2 diabetes and obesity and also the significant increase of

Table 1: The main histopathological types of colorectal cancer (Hamilton \& all 68 WHO Classification of Tumours of the Digestive System). diabetes in young adults certify the role of risk factor of diabetic disease in the onset of CRC [48-51]. Eating habits particular to young people in the USA, tripling the fast-food consumption from the 1970s until now, a supercaloric and rich in meat diet, especially in children, makes it plausible that the increased CRC incidence in young adults may be the consequence of this eating behavior $[13,52,53]$. On the other hand, the consumption of milk has shown a protective effect [54]. Other behavioral factors such as alcohol use and smoking are associated with increased risk of CRC [55-57].

Inflammatory bowel disease (IBD), ulcerative colitis (UC) and Crohn disease (CD), are well known to be premalignancies in patients with long-term disease, of at least 8-10 years (about $2 \%$ of CRC) [58-63]. The presence of IBD in the pregnant woman is similar to the incidence in the general population, the enteral inflammatory pathology appearing in childhood, with a peak of manifestations between 15-30 years. The occurrence of CRC in pregnancy is reported precisely on this background of long evolution of the disease (about 15-20 years), between the peak of the symptomatology and the pregnancy [64] (risk of occurrence of 2-3 times higher than in the population general) [65].

\section{Pathological Anatomy and Carcinogenesis}

The most common colorectal cancers in pregnancy are epithelial, $90 \%$ adenocarcinomas and $10 \%$ mucinous adenocarcinomas; the rest are considered rare types [66-68] (Table 1). Interesting to note, however, is the specificity of the young adult for rare types such as various carcinoids or colo-rectal lymphomas. Especially in young women, including pregnant women, colonic carcinoid, squamous rectal cancers and "transitional cell like" rectal cancers are reported [69]. Histo-carcinogenesis of CRC is not yet fully elucidated. Colonic polyps are involved in the onset of CRC. At least apparently, all cases of CRC derive from adenomatous polyps, an aspect confirmed by all epidemiological and clinico-pathological studies [70-73], the adenoma-cancer sequence being proven by current molecular studies. The evolution towards neoplasia crosses the known adenoma / polyp - low / high dysplasia - invasive carcinoma-like lesion cascade [74] (Table 2).

\begin{tabular}{|c|}
\hline Histopathologic Types of Colorectal Carcinoma - World Health Organisation Classification \\
\hline Adenocarcinoma, NOS (not otherwise specified) \\
\hline Mucinous adenocarcinoma (colloid) $(>50 \%$ mucinous) \\
\hline Signet ring carcinoma ( $>50 \%$ signet ring cell) \\
\hline Squamous cell carcinoma (epidermoid) \\
\hline Adenosquamous carcinoma \\
\hline Small cell carcinoma (oat-cell) \\
\hline Medullary carcinoma \\
\hline Undifferentiated carcinoma \\
\hline Other types ( Micropapillary carcinoma, Serrated adenocarcinoma, Cribriform comedo-type adenocarcinoma) \\
\hline
\end{tabular}


Table 2: Vienna classification of gastrointestinal epithelial neoplasia and the sequence of evolution towards neoplasia (Schlemper RJ \&all) [74].

\begin{tabular}{|c|c|}
\hline Category & Diagnosis \\
\hline Group 1 & Negative for neoplasia/dysplasia \\
\hline Group 2 & Indefinite for neoplasia/dysplasia \\
\hline Group 3 & $\begin{array}{c}\text { Mucosal low grade neoplasia - Non invasive } \\
\text { Low grade adenoma/dysplasia }\end{array}$ \\
\hline & \\
\hline Group 4 & Mucosal high grade neoplasia - Non-invasive \\
Subgroup 4.1 & - High grade adenoma/dysplasia \\
Subgroup 4.2 & - Non-invasive carcinoma (carcinoma in situ)* \\
Subgroup 4.3 & - Suspicion of invasive carcinoma \\
\hline Group 5 & Invasive neoplasia \\
Subgroup 5.1 & - Intramucosal carcinoma \\
Subgroup 5.2 & - Submucosal carcinoma or beyond \\
\hline
\end{tabular}

*Non-invasive indicates absence of evident invasion.

†Intramucosal indicates invasion into the lamina propria or muscularis mucosae.

In the histological criterion of evaluation of neoplasia and, of course, of prognosis, the tumor differentiation type (grading) has a major importance, being considered an independent element of evaluation [75-84] by the World Health Organization: Low Grade - well differentiated and moderately differentiated, High Grade poorly differentiated and undifferentiated (about $20 \%$ of cases). The better the tumor differentiation, respectively Low grade, the better prognosis is reported [85]. Surbone et al. [86] report in pregnant women a higher frequency of poorly differentiated and undifferentiated colorectal tumor or the presence of mucinous tumors (Figure 2). Additional specific histological assessment data of the tumor in the pregnant woman such as lymphatic invasion, vascular or perineural invasion, aneuploidy, etc. are missing in various studies, making a consistent assessment impossible, most probably due to the lack of a convenient statistical pool.

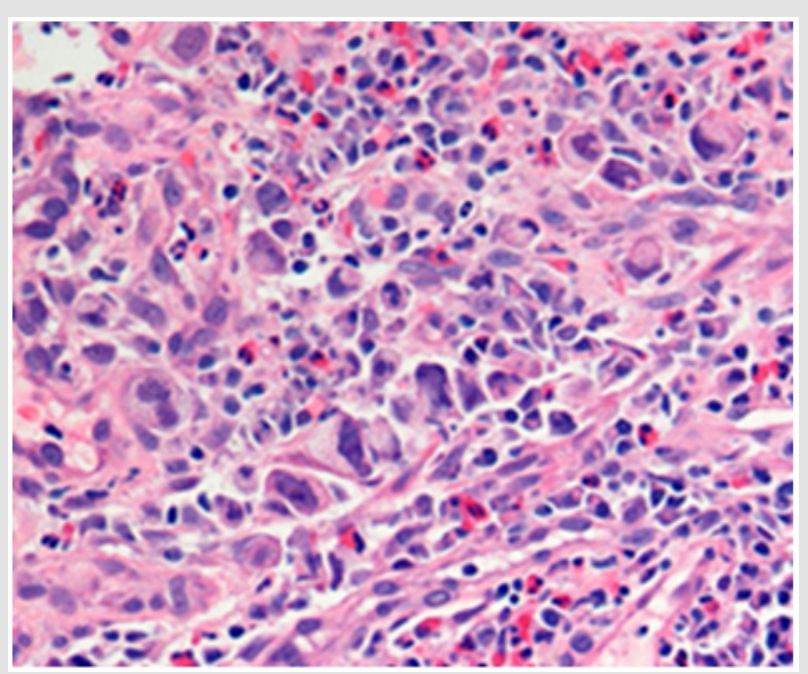

Figure 2: Histopathologic slide (magnification $x 40$ hematoxylin and eosin) suggestive appearance for poorly differentiated, signet ring cell carcinoma CRC (collection of the clinic).

\section{Clinical Diagnosis}

Clinical manifestations of CRC in pregnancy are masked by characteristic signs of pregnancy, all the more present as the pregnancy approaches the term: diffuse abdominal pain, meteorism, constipation, physical asthenia, possible rectal bleeding. The consequence will be the ignorance of the symptoms and the avoidance of the consultation with a doctor, with the progression of the neoplastic disease so that, most often, the diagnosis will reveal
CRC in an advanced phase. Often, even the doctor can neglect these manifestations, putting them on account of pregnancy-specific complications [87]. As a result, the physician should be alert to any new signs/symptoms, especially its persistence in pregnancy, and to consider the possibility of another pathology, such as CRC. Other less common manifestations would be unnatural weight loss, nausea and/or vomiting, malaise. In the onset of symptoms, it is important to locate the tumor, its dimensions, degree of invasion (metastasis). 
Cancer of the right colon are generally bulky, ulcerated, with an important sclerolipomatous peritumoral process, which is why they often appear to be more advanced than they actually are, hemorrhagic, usually with small but chronic bleeding, leading to unexplained anemia. Due to the minimal bleeding, the appearance is occult bleeding, and can only be detected by specific tests $[16,88]$. The anemia that accompanies the bleeding has the appearance of a iron deficiency anemia, with partial response to iron treatment, and may manifest the signes of weakness, fatigue, dyspnea or palpitations. In comparision, cancer of the left colon are causing most often stenosis, are small in size, causing transit disorders in the form of a constipation that does not respond to treatment, with subocclusive syndrome or even intestinal obstruction. Exceptionally, König-type manifestations may occur in pseudooclusive tumors - a period of severe constipation, with severe meteorism and colicative abdominal pain before the obstacle followed, paradoxically, by numerous diarrhea stools with obvious improvement in symptoms.

Evolution is cyclical, a similar episode can occur at any time. Bleeding often appears dark or maroon-colored and may be mixed with stool. Distal (rectal) neoplasms are rarely occlusive, the main manifestation usually is bleeding with a characteristic aspect: partially degraded blood of hematochezia, mixed with stool or red blood or blood clots before or at the end of defecation, possibly associated with rectal tenesms. This should not be confused with bleeding from hemorrhoids, often present and with a noisy symptomatology in pregnancy. In advanced CRC, metastatic, weight loss, anorexia, physical asthenia, poor health, constitute a symptomatic tetralogy specific to neoplastic cachexia [89]. Objective clinical examination is mandatory. During the inspection, the neoplastic impregnation can be found and, in the conditions of a complicated tumor, most commonly by perforation, a typical presentation is observed for an acute abdomen: patient is helding her hands on the abdomen, posturally bent forward, the respiratory movements are superficial, tachypnea, the abdominal wall is not moving in inhale/exhale.

At the palpatory examination, in the case of the right colon tumors, a tumor localized in the right fossa and right flank may be detected. This is facilitated on the one hand by the superficial situation of the right colon compared to the left one as well as by the important dimensions of the tumors in the right colon, due to the inflammatory phenomena and the appearance of peritumoral lipomatous sclerosis but, on the other hand, as the pregnancy progresses. The maneuver can be made more difficult. In the left colon the tumor is most often hardly detectable, on the one hand due to the deep location of the left colon and on the other hand, because the tumor dimensions that would make palpatory detection possible are only rarely reached before the appearance of complications. The identification of a distended colon, confirmed by percussion, accompanied by abdmonial pain, spontaneous or after palpation, may suggest a partial ot total obstruction. However, the clinical interpretation is not easy in pregnant women, especially at an advanced age of pregnancy.

It is also difficult to identify signs of advanced neoplasm (hepatomegaly, ascites, carcinomatosis) or the Sister Mary Joseph sign (palpable umbilical metastasis) but their clinical value is low and non-specific to CRC. The search for peripheric adenopathies, although rarely discovered, such as the Virchow-Troisier sign, is mandatory. Vaginal and rectal examination [90] allow the identification of any lesions, including tumors, up to about 8-10 cm from the anus. Palpation provides data on the location of a tumor in this range, the possible extent of the tumor, the characteristics of the tumor (vegetative, ulcerated), local invasion. Associated with vaginal examination, bidigital palpation of the recto-vaginal septum provides information about the anterior extension of the rectal tumor. The examination of the exploratory finger will allow to appreciate the quality and the appearance of a possible rectal bleeding, facilitating the diagnosis.

\section{Evolution and Complications}

The occurrence of CRC complications in pregnant women causes a poor prognostic factor, both immediately (vital) and also on a long term, both for mother and fetus. CRC evolution has a slow progression (from the onset until it becomes clinically detectable it has a history of about 1.5-2 years). Quite often, the appearance of a complication is relevant for the diagnosis, in the conditions of a completely asymptomatic or at least non-specific evolution, as is the case with the pregnant women. Complete or quasi-complete tumor stenosis causes sub-occlusive or occlusive syndromes. If the tumor volume is important, compression phenomena are possible on the neighboring organs: bladder, ureter, iliac vessels. Tumor perforation can be perforation in the tumor or on the juxtatumoral segment, and diastatic perforation (remote perforation, especially in the region of the caecum and ascending colon, if the ileal valve is competent). When there is a degree of reactivity, the tumor perforation can be covered with the greater omentum and neighboring organs, evolving in a confined space. The result will be a blocked hyperseptic peritonitis - perineoplastic abscess. When the tumor perforation is in the large cavity, the consequence is a diffuse faecal peritonitis, extremely severe and with an unfavorable prognosis.

Chronic bleeding is not considered an evolutive complication; only severe bleeding, externalized as lower digestive hemorrhages (hematochesis). Frequently, bleeding is not very abundant, it stops spontaneously and recurs capriciously, unrelated to food or other phenomena. That is why it is considered the mildest of the evolutive complications of colon cancer. In evolution, the tumor invasion in the neighboring organs allows the erosion of histological barriers with the establishment of internal fistulae in the cavitary organs (stomach, duodenum, small bowell, bladder) or externally, to the abdominal wall. Neoplastic metastases are evidence of a late- 
stage disease: lymph node and hepatic metastases, peritoneal carcinomatosis and carcinomatous ascites and, more rarely, metastases in the lungs, bones, ovaries. Some complications are caused by the interference of the body with the metabolism of the atypical process, leading to severe hypoproteinemia with cachexia, severe hydro-electrolytic disorders in the occlusive clinical forms. Acute symptoms and symptoms of the neighboring organs can occur acute cholecystitis, acute appendicitis, revealing the real diagnosis.

\section{Paraclinic Diagnosis}

\section{Screening Tests}

In many countries, in last years, fecal occult blood testing (FOBT) through the Haemoccult test in pregnant women is common use. The test is more specific for left colon cancers and can cause false positive and false negative results (consumption of red meat, broccoli, iron medication, aspirin or derivatives, anticoagulants, etc.) [91-93]. Even in ideal conditions, only 5-10\% of patients tested were found to have CRC and another $20-30 \%$ were found to have adenomatous polyps [94-96]. The false negative results keep the patients in observation for the repetition of the method, and the false positive results are confirmed by the extension of the explorations. When possible, the pregnant woman enters a surveillance and reconfirmation program through a new test and is subsequently further investigated $[97,98]$.

\section{Laboratory Tests}

Without offering a diagnosis of certainty, they highlight changes that suggest a neoplastic pathology: unexplained chronic anemia (without another detectable cause), which takes the form of a chronic blood loss $[99,100]$, hypochromic, microcytic, hyposideremic, leukocytosis with a predominance of neutrophils resulting from tumor superinfection and increased inflammatory indices (ESR, fibrinogen). In case of increased alkaline phosphatase, aminotransferases and bromsulfaphtale retention, the possibility of liver metastases is suspected; high levels of alkaline phosphatase concomitant with those of calcium raise the suspicion of bone metastases [101]. Immunological tests (carcinoembryonic antigen -ACE, $\alpha$-fetoprotein, CA 19-9) are lacking in specificity, having no diagnostic value in the early stages, but their role is gaining importance in postoperative oncological monitoring, signaling the occurrence of metastases [102-108]. Currently, their value is normal in pregnant women, not being influenced by pregnancy, or there is only a slight increase, without pathological significance [109]. However, high levels of tumoral markers are correlated with a poor prognosis. After complete colic resections, the values should normalize. However, persistent high values suggests that the surgery was not curative, insufficient and, of course, overestimated $[110,111]$. Return to normal values after surgery, followed after a while by a significant increase, suggests recurrence [112-114].

\section{Barium Enema}

Radiological examination of the lower GI is used very successfully in the diagnosis of CRC, but the pregnant woman represents a particular situation that limits the medical indication of this method only in exceptional cases. Irigography is criticized because of the mutagenic, teratogenic and carcinogenic effect of ionizing radiation. The appearance of the side effects above depends on the dose administered (measured in cGy), the conformational structure of the pregnant woman, the trimester of pregnancy, the treatments administered, etc. Current data recommends avoiding radiation greater than 5-10 cGy. Up to this irradiation threshold, the risks are associated with a low level of mutagenicity (stochastic biologic effects) and has no "non-stochastic" type effects (malformations, developmental pathologies) [115-117]. The average dose of irradiation per case is only $0,3 \mathrm{cGy}$, well below the recommended threshold for pregnant women.

However, in the first trimester, in fact the most important and risky period for the fetus, parsimony is recommended in the indication for barium enema. The diagnostic sensitivity of the method is about $83 \%$, slightly lower than that of colonoscopy [118]. The method can be supplemented by air insufflation, which allows double-contrast examination (Fischer test). Barium enema provides information about the location of the tumor, their number, the tumor impact on the digestive tract and an overall configuration of internal morphology, extremely useful in therapeutic decisions. A defect of the technique is due to the particular situation in pregnant women, especially in the advanced stages of pregnancy, altering the diagnostic interpretation by masking and possibly displacing the colon and/or tumor. Barium enema also has obvious advantages: cheap, less invasive and safer compared to colonoscopy (extremely low perforation risk - about 1 per 25000 examinations) [119].

Endoscopy (rectosigmoidoscopy, colonoscopy) allows direct, macroscopic diagnosis and by direct biopsy sampling of the lesion. The risks of the method are not to be neglected [120,121]: placental abruption as a consequence of luminal insufflation with pressure on the uterus, various fetal injuries secondary to hypotension or maternal hypoxia during exploration by deep sedation, teratogenic effects due to the administred medication, enteral perforation due to difficulty technique, etc. In a study on 192 cases, to minimize maternal-fetal risks, Dark and Campbell [122], recommend: administration of oxygen to the patient during the maneuver, gentle handling and minimization of insufflation pressure, positioning the pregnant woman in the left lateral decubitus to lower the pressure in the inferior vena cava, sedation with meperidine and not with diazepam/midazolam due to the minimal effect on the fetus, fetal cardiac monitoring [123]. Colonoscopy is indicated only in case of CRC suspicion.

Recto-sigmoidoscopy or partial colonoscopy is convenient due to the patient's much greater tolerance for exploration, minimal risk 
for possible congenital malformations or abortion induction [124126], fast and effective, but provides information for lesions up to about $40 \mathrm{~cm}$ from the anocutaneous margin [125,127]. However the risk of leaving synchronous lesions above the distal tumor $5 \%$ of cases), makes recto sigmoidoscopy a "second hand" method, which can be used whenever we cannot perform a colonoscopy. Therefore, the colonoscopic examination should not stop at the first lesion encountered and should progress as much as possible. In general, it is recommended that biopsy prelevation should be made from the edges of the ulcerative lesion. The association of the endoscopic ultrasound examination (intraluminal ultrasound) confers valuable information in assessing the degree of parietal invasion by the tumor, allowing the evaluation of the $\mathrm{T}$ index in the TNM classification. Completing the colonoscopic examination with the cytological examination obtained by direct brushing of the tumor through the endoscope or the cells exfoliated from the enema fluid or during the endoscopic examination allows the diagnostic index to be increased [128-129].

Standard abdominal ultrasound has a limited diagnostic role, usually for the assessment of staging ( $\mathrm{M}$ index - metastases): liver metastases (sensitivity of $75-80 \%$ ) or other abdominal disseminations. $t$ can be used to guide needle biopsies. The US cannot detect metastatic determinations cu sizes below one centimeter. Endoscopic ultrasound, especially the transrectal ultrasound, brings additional details for $\mathrm{T}$ (parietal invasion) and $\mathrm{N}$ (lymphadenopathy) indices from TMN staging. The comparison regarding the accuracy in the evaluation of $\mathrm{T}$, on large studies, shows that for CT the value is $75 \%$ and $85 \%$ for echo-endoscopy, respectively [130-138]; for $\mathrm{N}$ the values are between $54 \%$ for CT respectively 73\% - 83\% for EUS. In assessing regional lymph node status (N1), recent papers [131-134,139] shows a positive predictive value of $86 \%$. A special indication of EUS: anterior or large rectal tumors, which can invade the rectum-vaginal septum and vagina, contraindicating natural birth [140].
Whenever the ganglionic aspect of the EUS is abnormal, the guided needle becomes mandatory (EUS FNA) - "gold standard" . The combination of the two methods increases the positive prediction factor to $95 \%$ but there are few studies and experience in this regard. In the anterior secondary invasion that is not more than $3 \mathrm{~cm}$ away from the rectal parietal border, EUS is considered much more valuable compared to CT. In contrast, as the distance increases, EUS can no longer provide data on possible secondary determinations, due to low tissue penetrability or, the presence of obstructive tumors (up to $50 \%$ of cases) that cannot be exceeded by the exploratory endoscope, or by the oncological treatments that also interfere with the method [133,141-144].

\section{Computed Tomography}

Essential in terms of assessing the staging of TNM in CRC, CT remains the subject of numerous debates. Of course, whenever the method can be avoided, it is good not to use this technique. If CT can be evocative for a diagnosis, especially in case of a major complication (Figure 3), or as a therapeutic guide, the practitioner should not hesitate to use it, the life of the mother being considered more valuable than that of the fetus (!). What can CT bring to the assessment of neoplasia during pregnancy? First of all, the method allows a three-dimensional evaluation of the colon-rectum relations with the adjacent structures. Secondly, the appreciation and demonstration of complications that are not apparent or lead to a rapid adverse evolution of the mother in the absence of a clear or obvious diagnosis, which puts her life in immediate danger, especially in the absence of rapid and effective treatment (perforations, obstructions, etc.) $[145,146]$. Third, an appreciation of staging. After an initial enthusiasm, in which CT was accredited with an accuracy of $85-90 \%$ in assessing the $\mathrm{T}$ index from TNM staging, high-rigorous studies [146-149] proved a much lower rate, between $50-70 \%$, dependent of the lesion stage (the accuracy for the T4 lesion is much better compared to that of T2 or T3).

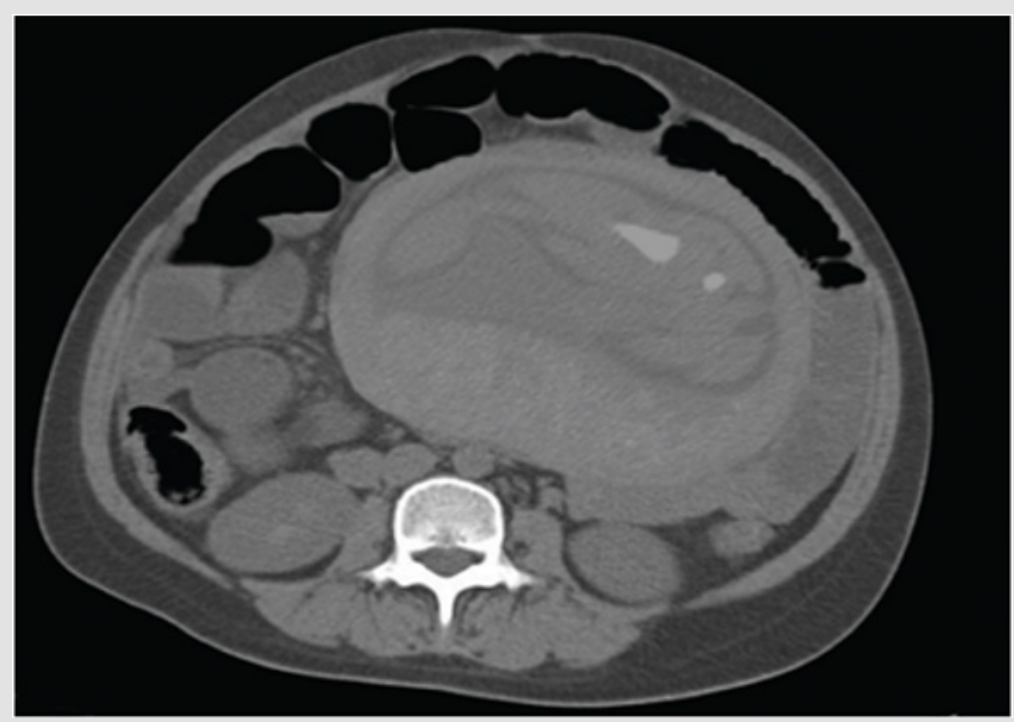

Figure 3: Pregnant CT scan showing an occlusive complication of a recto-sigmoid junction CRC (collection of the clinic). 
Overestimation of the T-index is the most common problem [150]. Particularly for rectal cancer and especially in pregnancy, when zonal changes are important and may alter the accuracy of the method, inflammatory perirectal fibrous bundles may be confused with perirectal tumor infiltration, overestimating the tumor [151]. The dimensional limits of the method are somewhere around $1 \mathrm{~cm}$. Therefore, the detection of lymphadenopathy ( $\mathrm{N}$ index) remains a problem as long as they do not exceed this value. That is why the specificity in detection $\mathrm{N}$ is only $45 \%$ (!) [145]. The essential role of $\mathrm{CT}$ is to assess the $\mathrm{M}$ index, identifying liver metastases with an accuracy of $85 \%$ and a specificity of $97 \%$ [148]. The data are somewhat superimposable with those obtained by MRI [149]. Over the last 40 years CT has been contraindicated in pregnant women due to teratogenic and carcinogenic effects on the fetus. The introduction of spiral CT drastically diminished the irradiation during the exploration, an entire segment (eg abdomen or pelvis) being traversed in about 17-19 seconds for sectional fields at 1.25 $\mathrm{mm}$. For this reason, the CT method has been re-evaluated for use in pregnant women.

The teratogenic effect of CT radiation is non-cumulative (nonstochastic). The most susceptible period to the teratogenic effects of CT irradiation corresponds to the organogenesis period, especially during the 2-15 weeks of pregnancy. Teratogenic complications include [152]: mental retardation, growth deficiencies, microcephaly, microphthalmia, behavioral deviations, cataracts. The threshold irradiation dose [153], under which no teratogenic effects occur, it is not clearly known but it appears to be between 5 and 15 cGy. During a spiral CT the dose administered to the fetus is variable [154-158], depending on a number of elements (eg examination parameters), between 2.9-4.4 cGy, irradiating dose well below the critical threshold at congenital malformations [159]. The carcinogenic effect over time of CT is cumulative (stochastic), there is no threshold dose. There is also a dependence between the time of radiation exposure in pregnancy and the risk of carcinogenesis. The smaller the pregnancy, the higher the risk $[160,161]$.

It is estimated that at the average dose used (2-5 cGy) for a CT, the risk of childhood cancer doubles. However, the value is very low, the recommendations of the American College of Obstetrics and Gynecology are significant: "very low carcinogenic risk, abortion is not recommended" [157,158,162,163]. A problem also arises regarding the use of contrast media. No mutagenic/ teratogenic effects were found in the in vivo studies $[164,165]$. The use of iodinated contrast media would have a potential to develop fetal hypothyroidism [166,167] but these reluctances have also been removed by newer studies $[168,169]$, which do not find any side effects in the thyroid function of the child after exposure to them in the fetal period. A promising option for the evaluation of pregnant women is virtual colonoscopy (CT colonography) due to the use of low doses of irradiation and a reduced "aggressiveness" of the method [170,171]. With an excellent accuracy of $81 \%$ and a sensitivity of $93 \%$, the technique will have a lot to say in the future but, for the moment, there are not enough data regarding the application of the method to pregnant women.

Magnetic resonance image is the variant used in pregnant women instead of CT to assess the stage of CRC, having the possibility to provide: information and complex topographic relationships (in three planes), allows the differentiation of tumor recurrences from postoperative fibrous remodeling.It is considered that regarding the staging indices of remote determinations ( $\mathrm{N}$ and $\mathrm{M}$ ), the method has similar CT limitations but with much higher costs [148]. The landmarks to be followed are the same as those in CT exploration. The major disadvantage is the presence of artifacts, secondarily induced by enteral peristaltic movements, respiratory movements, with degradation of image quality (scanning takes between 5 and 10 minutes). A newer innovation, endoscopic MRI (!), is at least as effective as EUS in assessing parietal tumor invasion [172-174]. Some studies find a significant improvement in the accuracy of the T-index assessment, with a sensitivity of $100 \%$ and a specificity of $86 \%$. The lackt of the method is the poor identification of the central or intermediate ganglia (mesenteric, rectal, etc.); here, the classical MRI is much superior [175-177].

MRI also plays an important role [178,179] in accurately predicting circumferential parietal extension (86\%) (sensitivity $94-100 \%$, specificity $85-88 \%$ ) as well as in assessing mesorectal invasion in rectal cancers [180-182], both of which are prognosis and surgical management criteria. There is a controversy regarding the safety of the method in the case of pregnant women, for possible teratogenic effects of magnetic fields and a possible acoustic damage to the fetus. In vivo studies on animals of Heinrichs et al. [183] and Tyndall [184] respectively showed the presence of malformations following exposure to magnetic fields (eg ocular malformations), the death or malformations of embryos when the exam is performed during organogenesis [185]. As a result, although no similar effects have been shown in humans, the guidelines of the National Radiological Protection Board from UK [186] recommends: "it is prudent to avoid MRI in pregnant women during the first three months of pregnancy". The possible acoustic effects induced in the fetus by the high sound level during MRI, are more theoretical, without really constituting an obvious threat $[187,188]$ and regarding the contrast medium, no teratogenic effects have been reported $[189,190]$.

In conclusion, in the first trimester of pregnancy MRI will be performed especially for maternal and less fetal indications. The method is preferable to any other method of investigation that uses ionizing radiation [191]. Regarding other CRC diagnostic methods using nuclear techniques, such as PET-CT, these are not in the current use for assessment in pregnant women but, for selected cases, some specific recommendations can be made (18F-FDG dose reduction, the use of the $3 \mathrm{D}$ technique that would allow the decrease of the 18F-FDG dose, a good hydration, attenuation of CT voltage, etc). The role of PET-CT in the evaluation of CRC is to identify the 
tumor site and assess the degree of distant invasion (metastatic lymphadenopathy, distant metastases). Technological development has allowed the cumulative radiation doses to the fetus during and after PET-CT to be at absolutely convenient levels (between 1 and 2 cGy), comparable or even lower than those administered by spiral CT [192-194].

Table 3: Classification list for CRC Stage - 1. American Joint Committee on Cancer (AJCC) and the International Association of Cancer (UICC) - TNM classification, 2. Duke and 3. Modified Astler-Coller system.

\begin{tabular}{|c|c|c|c|}
\hline \multicolumn{4}{|c|}{ Classification List for CRC } \\
\hline & Dukes & Astler-Coller & TNM \\
\hline Tumor invasion confined to the mucosa & A & $\mathrm{A}$ & Tis, N0 \\
\hline $\begin{array}{l}\text { Tumor invasion limited to the submucosa, no lymph node } \\
\text { involvement }\end{array}$ & A & B1 & $\mathrm{T} 1, \mathrm{~N} 0$ \\
\hline $\begin{array}{l}\text { Tumor invasion limited to the submucosa, lymph node } \\
\text { involvement }\end{array}$ & $\mathrm{C}$ & C1 & $\mathrm{T} 1, \mathrm{~N} 1-2$ \\
\hline $\begin{array}{l}\text { Limited tumor invasion into the muscle layer, no lymph } \\
\text { node involvement }\end{array}$ & A & B2 & T2, N0 \\
\hline $\begin{array}{l}\text { Limited tumor invasion into the muscle layer, lymph node } \\
\text { involvement }\end{array}$ & $\mathrm{C}$ & $\mathrm{C} 1$ & $\mathrm{~T} 2, \mathrm{~N} 1-2$ \\
\hline $\begin{array}{l}\text { During the whole muscle layer tumor involvement, no } \\
\text { lymph node involvement }\end{array}$ & $\mathrm{B}$ & B2 & T3, N0 \\
\hline $\begin{array}{l}\text { During the whole muscle layer tumor involvement, lymph } \\
\text { node involvement }\end{array}$ & $\mathrm{C}$ & $\mathrm{C} 2$ & $\mathrm{~T} 3, \mathrm{~N} 1-2$ \\
\hline $\begin{array}{c}\text { Tumors have kept the neighboring organs, no lymph node } \\
\text { involvement }\end{array}$ & $\mathrm{B}$ & B2 & $\mathrm{T} 4, \mathrm{~N} 0$ \\
\hline $\begin{array}{c}\text { Tumors have kept the neighboring organs, lymph node } \\
\text { involvement }\end{array}$ & $\mathrm{C}$ & $\mathrm{C} 2$ & $\mathrm{~T} 4, \mathrm{~N} 1-2$ \\
\hline Other factors notwithstanding distant metastases & $\mathrm{D}$ & $\mathrm{D}$ & $\mathrm{T} 1-4, \mathrm{~N} 0-2, \mathrm{M} 1$ \\
\hline
\end{tabular}

\section{Prognosis and Evolution}

The prognosis in CRC in pregnant women targets the two partners: mother and foetus. Maternal prognosis for CRC discovered during pregnancy is poor. This is because the tumor is discovered late, in an advanced stage of the disease. Maybe that's why the prognosis of rectal neoplasia is slightly better than that of colon cancer, because distal malignancy is revealed earlier (see clinical signs) [18]. Comparatively, for the same evolutionary stage with the general population, the survival index has no different values [195]. In some studies, cases with 5-year survival are not reported, reinforcing the conclusion of a poor prognosis of CRC in pregnant women [15]. Also, Chan et al. [196] on a review of 42 cases of colic cancers found that the vast majority of pregnant women had died 1 year after the time of diagnostic, the average survival period being less than 5 months (!). Only one patient achieved a survival period of 3.5 years and, of all the patients in the literature studied, none survived up to 5 years. In cases with colic tumors, the presence of a chorionic gonadotrophin secretion associated with aggressive types of neoplasia was noted: mucinous adenocarcinoma, poorly differentiated or undifferentiated cancer cells, extensive invasion in neighboring organs or distance invasion.

Due to these findings, the chain gonadotrophin - aggressive type of cancer - unfortunate prognosis in pregnant women is

\section{Stage and Prognosis}

In current practice, several systems for assessing staging (TNM, Duke or modified Astler-Coller) have been developed; however, the most widespread is the one introduced by AJCC and The Union for International Cancer Control (UICC), the TNM system (Table 3). suspected [197-201]. The indices of metastatic invasion (liver, ovary, etc.) are similar to those in the general population, the prognosis being negative (about $1 / 4$ of women with CRC have secondary ovarian determinations) [202-207]. Fetal prognosis. Hematogenous vertical mother-fetal transmission appears to be possible but is an exceptional event, the placental barrier and the fetal immune system appear to have a protective role. Fetal metastases from colorectal cancers have not been reported [208210]. More important are the consequences on the fetus after oncosurgical therapies. Induction of malformations, carcinogenic risk, developmental or cerebral disorders, abortion or even fetal death are some of the possible pathologies secondary to chemotherapy or other medical maneuvers; on the other hand, major surgery during pregnancy reports infant mortality rates of about $20 \%$ (!) $[15,211,212]$.

\section{Treatment}

The CRC's treatment plan must take into account the interests of two people, the mother and the foetus, so that the "interest" of one does not affect the other, respecting an axiom: treatment as soon as possible for the mother after a birth as soon as possible for the foetus. Therapeutic protocols undergo changes both in terms of the sequence of methods used and times to follow, which is why optimal management requires a multidisciplinary approach 
oncologist-obstetrician-surgeon-anesthetist-neonatologist and sometimes surgery in mixed teams obstetrician-surgeon. The family should not be excluded from these decisions, nor should a series of legal, ethical, religious or personal-emotional considerations be neglected. The essential factors on which the therapeutic protocol to follow depends tumor location, stage, tumor complications, type of presentation to the doctor (chronic vs. emergency), age of pregnancy and associated pathologies other than cancer, patient's decision [87]. Colorectal neoplasia is generally a predominantly surgical pathology at the time of disease discovery, especially in conditions of a major complication that leaves no time for a therapeutic alternative (obstruction, perforation, significant bleeding).

The rules of oncological surgery are mandatory: enteral excision depending on the location of the tumor with lymphadenectomy. For right colonic tumors, right ileo-hemicolectomy is performed and for tumors in the left colon, left hemicolectomy, possibly only segmental resection (splenic angle colectomy, sigmoidectomy, recto-sigmoid resection) - Figure 3. For low rectal tumors, the most likely technique is that of Miles abdominoperineal resection of the rectum with a definitive left iliac anus. Diagnosis of neoplasia in the first half of pregnancy, makes ablative surgery necessary, the time too long until the foetus becomes viable substantially increasing the risk of tumor progression. Depending on the tumor stage, abortion to speed up CRC treatment seems to be the option to choose [213] Until 20-30 years ago, the risk of fetal death or abortion was significant after surgical resections (about 25\%), Woods [211] reporting normal newborns in 25 of 32 cases with CRC. Currently, due to the new anesthetic-surgical acquisitions and the laparoscopic approach, the risk of embryo-fetal death has decreased to about $4 \%$; even the risk of abortion has decreased drastically, yet having a rate twice as high as in the general population [214-219].

The risk of malformations is not different from the general population either; however, there is a slightly higher level of low birth weight. Particular situations such as invasion of the uterus or a difficult approach in the pelvis may require the operating team to sacrifice the uterus and, of course, the ovaries [15,215,220]. In complicated or advanced tumors, palliative techniques such as various by-passes or colostomy may be beneficial, allowing the foetus to reach an age which ensures viability. Diagnosis of neoplasia in the second half of pregnancy. The discovery of a CRC between weeks 20-28 most often requires alternative oncological protocols and, only later, once a suitable fetal age is reached, surgery. If the CRC is apparently localized, with operative perspectives, the operative expectation interval is long enough, about 3 months, which is why chemotherapy is the weapon that represents the solution of a surgical delay. Because at the age of 32-34 weeks the foetus is viable in over $95 \%$ of cases, as much as possible the birth should be provoked in / after this period. After a period of about 7-10 days necessary to reduce pelvic congestion, surgery is performed for tumor ablation, respecting the oncological principles already stated above [221].

For CRC ovarectomy is mandatory, the risk of microscopic insemination or remote metastases of Krukenberg type being very high, possibly being recommended to establish with fertility specialists the opportunity of fertility conservation techniques. The existence of particular situations requires the particular protocols. The impossibility of a natural birth, due to a utero-vaginal invasion by a rectal neoplasm with significant invasion to the anterior or a perineotomy with the risk of spreading the neoplasm, require a single operating time, starting by cesarean section and then continued with colorectal resection [87]. A chemotherapy-type oncology protocol option is preferred for cases with advanced, metastatic neoplasms, the purpose being obviously to prolong the mother's life until the moment of a "safe" birth. If the foetus is of a suitable age, chemotherapy provides a therapeutic option, although only palliative, to the pregnant woman and the mother in the postpartum period. In the latter situation, the decision of starting the chemotherapy belongs to the mother, who must understand the risks to the foetus, the limited effectiveness of treatment and, of course, take into account a number of moral, religious, ethical, etc.

The usual CRC regimens use antimetabolites (5-FU, methotrexate, etc.) and alkylating agents (cyclophosphamide, chlorambucil) and the most convenient dual formula, widely used, apparently with minimal effects on the foetus, the combination 5-FU + Leucovorin (folinated calcium) [222]. Vinca-derived antibiotics or alkaloids do not cause secondary fetal defects while etoposide induces pancytopenia and cisplatin hypoacusis or growth retardation. The therapeutic role and side effects of new agents (oxiplatin, irinotecan, capecitabine) are not well explored or documented. For example, Oxiplatin is classified by the Food and Drug Administration in category D toxicity, at risk of fetal injury [223]. Fetal toxicity regarding monotherapy vs. polychemotherapy shows a slight increase, from 17 to $25 \%$ in the case of multiple chemotherapy [224]. An opion would be the weekly therapy, especially the treatment with doxorubicin, paclitaxel, epirubicin, with minimal hematological effects in the mother and a much faster recovery for childbirth [225,226]. Chemotherapy should not be given after 33 weeks or 3 weeks before birth [227].

A particular case is represented by the low rectal cancers, located up to $10 \mathrm{~cm}$ from the ano-cutaneous line. For these, neoadjuvant oncological radiochemotherapy may be a possible solution in pregnant women in the second half of pregnancy. Radiation therapy can induce important side effects: carcinogenesis, mental or physical retardation, even fetal death. New IMRT techniques, with appropriate utero-fetal protection so that the dose of irradiation per pregnancy does not exceed $10 \mathrm{cGy}$, can provide a therapeutic variant in selected cases [228-231]. However, irradiation is recommended in the postpartum period and only if it is absolutely 
necessary during pregnancy, provided that the irradiation area is as far apart as possible from the foetus. Molecular treatments, such as targeted anti-EGFR therapy eg Cetuximab (Erbitux), have not been used and there are no studies to date to provide information on fetal side effects.

\section{References}

1. (2007) World Health Organization, Ten statistical highlights in global public health. World Health Statistics 2007. World Health Organization, Geneva, Switzerland.

2. Ferlay J, Shin HR, Bray F, Forman D, Mathers CD, et al. (2010) GLOBOCAN 2008, Cancer Incidence and Mortality Worldwide: IARC CancerBase No.10. Lyon, France: International Agency for Research on Cancer.

3. Center MM, Jemal A, Smith RA, Ward E (2009) Worldwide variations in colorectal cancer. CA Cancer J Clin 59(6): 366-378.

4. Center MM, Jemal A, Ward E (2009) International trends in colorectal cancer incidence rates. Cancer Epidemiol Biomarkers Prev 18(6): 16881694.

5. Altekruse SF, Kosary CL, Krapcho M, Neyman N, Aminou R, et al. (2010) SEER Cancer Statistics Review, 1975-2007, National Cancer Institute. Bethesda, based on November 2009 SEER data submission, posted to the SEER web site.

6. Ries L, Melbert D, Krapcho M, Stinchcomb DG, Howlader N, et al. (2008) SEER Cancer Statistics Review 1975-2005. Bethesda (MD): National Cancer Institute.

7. Chu KC, Tarone RE, Chow WH, Hankey BF, Ries LAG (1994) Temporal patterns in colorectal cancer incidence, survival, and mortality from 1950 through 1990. J Natl Cancer Inst 86(13): 997-1006.

8. Cress RD, Morris C, Ellison GL, Goodman MT (2006) Secular changes in colorectal cancer incidence by subsite, stage at diagnosis, and race/ ethnicity, 1992-2001. Cancer 107(5 Suppl): 1142-1152.

9. Phillips KA, Liang SY, Ladabaum U, Haas J, Kerlikowske K, et al. (2007) Trends in colonoscopy for colorectal cancer screening. Med Care 45(2): 160-167.

10. Isbister WH, Fraser J (1990) Large-bowel cancer in the young: a national survival study. Dis Colon Rectum 33(5): 363-366.

11. Nomura A (1990) An international search for causative factors of colorectal cancer. J Natl Cancer Inst 82(11): 894-895.

12. O'Connell JB, Maggard MA, Liu JH, Etzioni DA, Livingston EH, et al. (2003) Rates of colon and rectal cancers are increasing in young adults. Am Surg 69(10): 866-872.

13. Siegel RL, Jemal A, Ward E (2009) Increase in Incidence of Colorectal Cancer Among Young Men and Women in the United States. Cancer Epidemiol Biomarkers Prev 18(6): 1695-1698.

14. Medich DS, Fazio VW (1995) Hemorrhoids, anal fissure, and carcinoma of the colon, rectum, and anus during pregnancy. Surg Clin North Am 75(1): 77-88

15. Nesbitt JC, Moise KJ, Sawyers JL (1985) Colorectal carcinoma in pregnancy. Arch Surg 120(5): 636-640.

16. Cappell MS (1998) Colon cancer during pregnancy: the gastroenterologist's perspective. Gastroenterol Clin North Am 27(1): 225-256.

17. Minter A, Malik R, Ledbetter L, Winokur TS, Hawn MT, et al. (2005) Colon Cancer in Pregnancy, Cancer Control 12(3): 196-202.

18. Bernstein MA, Madoff RD, Caushaj PF (1993) Colon and rectal cancer in pregnancy. Dis Colon Rectum 36(2): 172-178.

19. Lichtenstein P, Holm NV, Verkasalo PK, Iliadou A, Kaprio J, et al. (2000) Environmental and heritable factors in the causation of cancer--analyses of cohorts of twins from Sweden, Denmark, and Finland. N Engl J Med 343(2): 78-85.
20. Fernebro E, Halvarsson B, Baldetorp B, Nilbert M (2002) Predominance of CIN versus MSI in the development of rectal cancer at young age. BMC Cancer 2: 25.

21. Kapiteijn E, Liefers GJ, Los LC, Kranenbarg EK, Hermans J, et al. (2001) Mechanisms of oncogenesis in colon versus rectal cancer. J Pathol 195(2): 171-178.

22. Fearon ER, Vogelstein B (1990) A genetic model for colorectal tumorigenesis. Cell 61(5): 759-767.

23. Frattini M, Balestra D, Suardi S, Oggionni M, Alberici P, et al. (2004) Different genetic features associated with colon and rectal carcinogenesis. Clin Cancer Res 10(12 Pt 1): 4015-4021.

24. Colombino M, Cossu A, Manca A, Dedola MF, Giordano M, et al. (2002) Prevalence and prognostic role of microsatellite instability in patients with rectal carcinoma. Ann Oncol 13(9): 1447-1453.

25. Gervaz P, Bouzourene H, Cerottini JP, Chaubert P, Benhattar J, et al. (2001) Dukes B colorectal cancer: distinct genetic categories and clinical outcome based on proximal or distal tumor location. Dis Colon Rectum 44(3): 364-372.

26. Aaltonen L, Johns L, Järvinen H, Mecklin JP, Houlston R (2007) Explaining the familial colorectal cancer risk associated with mismatch repair (MMR)-deficient and MMR-stable tumors. Clin Cancer Res 13(1): 356361.

27. Vogelstein B, Kinzler KW (2004) Cancer genes and the pathways they control. Nat Med 10(8): 789-799.

28. Aretz S, Uhlhaas S, Caspari R, Mangold E, Pagenstecher C, et al. (2004) Frequency and parental origin of de novo APC mutations in familial adenomatous polyposis. Eur J Hum Genet 12(1): 52-58.

29. Westerman AM, Entius MM, Boor PP, Koole R, De Baar E, et al. (1999) Novel mutations in the LKB1/STK11 gene in Dutch Peutz-Jeghers families. Hum Mutat 13(6): 476-481.

30. Schreibman IR, Baker M, Amos C, Mc Garrity TJ (2005) The hamartomatous polyposis syndromes: a clinical and molecular review. Am J Gastroenterol 100(2): 476-490.

31. Morak M, Laner A, Scholz M, Madorf T, Holinski Feder E (2008) Report on de-novo mutation in the MSH2 gene as a rare event in hereditary nonpolyposis colorectal cancer. Eur J Gastroenterol Hepatol 20(11): 1101-1105.

32. Plasilova M, Zhang J, Okhowat R, Marra G, Mettler M, et al. (2006) A de novo MLH1 germ line mutation in a 31-year-old colorectal cancer patient. Genes Chromosomes Cancer 45(12): 1106-1110.

33. Win AK, Jenkins MA, Buchanan DD, Clendenning M, Young JP, et al. (2011) Determining the frequency of de novo germline mutations in DNA mismatch repair genes. J Med Genet 48(8): 530-534.

34. Slattery ML, Samowitz WS, Holden JA (2000) Estrogen and progesterone receptors in colon tumors. Am J Clin Pathol 113(3): 364-368.

35. Korenaga D, Orita H, Maekawa S, Itasaka H, Ikeda T, et al. (1997) Relationship between hormone receptor levels and cell-kinetics in human colorectal cancer. Hepatogastroenterology 44(13): 78-83.

36. Geelhoed GW, Alford C, Lippman ME (1985) Biologic implications of steroid hormone receptors in cancers of the colon. South Med J 78(3): 252-254.

37. Francavilla A, Di Leo A, Polimeno L, Conte D, Barone M, et al. (1987) Nuclear and cytosolic estrogen receptors in human colon carcinoma and in surrounding non-cancerous colonic tissue. Gastroenterology 93(6): $1301-1306$

38. Hendrickse CW, Jones CE, Donovan IA, Neoptolemos JP, Baker PR (1993) Oestrogen and progesterone receptors in colorectal cancer and human colonic cancer cell lines. Br J Surg 80(5): 636-640.

39. Xu X, Thomas ML (1994) Estrogen receptor-mediated direct stimulation of colon cancer cell growth in vitro. Mol Cell Endocrinol 105(2): 197201. 
40. Lim H, Paria BC, Das SK, Dinchuk JE, Langenbach R, et al. (1997) Multiple female reproductive failures in cyclooxygenase 2 -deficient mice. Cell 91: 197-208.

41. Majerus PW (1998) Prostaglandins: critical roles in pregnancy and colon cancer. Curr Biol 8(3): R87-R89.

42. Terry PD, Miller AB, Rohan TE (2002) Obesity and colorectal cancer risk in women. Gut 51(2): 191-194.

43. Slattery ML, Ballard Barbash R, Edwards S, Caan BJ, Potter JD (2003) Body mass index and colon cancer: an evaluation of the modifying effects of estrogen (United States). Cancer Causes Control 14(1): 75-84.

44. Reeves GK, Pirie K, Beral V, Green J, Spencer E, et al. (2007) Cancer incidence and mortality in relation to body mass index in the Million Women Study: cohort study. BMJ 335(7630): 1134.

45. Troiano RP, Flegal KM (1998) Overweight children and adolescents: description, epidemiology, and demographics. Pediatrics 101(3 Pt 2): 497-504.

46. Flegal KM, Carroll MD, Kuczmarski RJ, Johnson CL (1998) Overweight and obesity in the United States: prevalence and trends, 1960-1994. Int J Obes Relat Metab Disord 22(1): 39-47.

47. Ogden CL, Carroll MD, Curtin LR, Mc Dowell MA, Tabak CJ, et al. (2006) Prevalence of overweight and obesity in the United States, 1999-2004. JAMA 295(13): 1549-1555.

48. Larsson SC, Orsini N, Wolk A (2005) Diabetes mellitus and risk of colorectal cancer: a meta-analysis. J Natl Cancer Inst 97(22): 1679-1687.

49. Skyler JS, Oddo C (2002) Diabetes trends in the USA. Diabetes Metab Res Rev 18 Suppl 3: S21-26.

50. Engelgau MM, Geiss LS, Saaddine JB, Boyle JP, Benjamin SM, et al. (2004) The evolving diabetes burden in the United States. Ann Intern Med 140(11): 945-950.

51. Larsson SC, Wolk A (2006) Meat consumption and risk of colorectal cancer: a meta-analysis of prospective studies. Int J Cancer 119(11) 2657-2664.

52. Guthrie JF, Lin BH, Frazao E (200) Role of food prepared away from home in the American diet, 1977-78 versus 1994-96: changes and consequences. J Nutr Educ Behav 34(3): 140-150.

53. Pereira MA, Kartashov AI, Ebbeling CB, Van Horn L, Slattery ML, et al. (2005) Fast-food habits, weight gain, and insulin resistance (the CARDIA study): 15-year prospective analysis. Lancet 365(9453): 36-42.

54. Cho E, Smith-Warner SA, Spiegelman D, Beeson WL, Van Den Brand PA, et al. (2004) Dairy foods, calcium, and colorectal cancer: a pooled analysis of 10 cohort studies. J Natl Cancer Inst 96(13): 1015-1022.

55. Ferrari P, Jenab M, Norat T, Moskal A, Slimani N, et al. (2007) Lifetime and baseline alcohol intake and risk of colon and rectal cancers in the European prospective investigation into cancer and nutrition (EPIC). Int J Cancer 121(9): 2065-2072.

56. Paskett ED, Reeves KW, Rohan TE, Allison MA, Williams CD, et al. (2007) Association between cigarette smoking and colorectal cancer in the Women's Health Initiative. J Natl Cancer Inst 99(22): 1729-1735.

57. Botteri E, Iodice S, Bagnardi V, Raimondi S, Lowenfels AB, et al. (2008) Smoking and colorectal cancer: a meta-analysis. JAMA 300(23): 27652778.

58. Ekbom A, Helmick C, Zack M, Adami HO (1990) Ulcerative colitis and colorectal cancer. A population-based study. N Engl J Med 323(18): 1228-1233.

59. Eaden JA, Abrams KR, Mayberry JF (2001) The risk of colorectal cancer in ulcerative colitis: a meta-analysis. Gut 48(4): 526-535.

60. Winther KV, Jess T, Langholz E, Munkholm P, Binder V (2004) Long-term risk of cancer in ulcerative colitis: a population-based cohort study from Copenhagen County. Clin Gastroenterol Hepatol 2(12): 1088-1095.
61. Langholz E, Munkholm P, Davidsen M, Binder V (1992) Colorectal cancer risk and mortality in patients with ulcerative colitis. Gastroenterology 103(5): 1444-1451

62. Lakatos PL, Lakatos L (2008) Risk for colorectal cancer in ulcerative colitis: Changes, causes and management strategies. World J Gastroenterol 14(25): 3937-3947.

63. Bernstein CN, Blanchard JF, Kliewer E, Wajda A (2001) Cancer risk in patients with inflammatory bowel disease: a population based study. Cancer 91(4): 854-862.

64. Andres PG, Friedman LS (1999) Epidemiology and the natural course of inflammatory bowel disease. Gastroenterol Clin North Am 28(2): 255281.

65. Von Roon AC, Reese G, Teare J, Constantinides V, Darzi AW, et al. (2007) The risk of cancer in patients with Crohn's disease. Dis Colon Rectum 50(6): 839-855.

66. Bosman FT, Carneiro F, Hruban RH, Theise ND (2010) WHO Classification of Tumours of the Digestive System. IARC Press 3(3).

67. Jass JR (2007) Classification of colorectal cancer based on correlation of clinical, morphological and molecular features. Histopathology 50(1): 113-130.

68. Hamilton SR, Rubio CA, Vogelstein B (2000) World Health Organization classification of tumours. Tumours of the digestive system. IARC Press $1(1)$.

69. Di Sario JA, Burt RW, Kendrick ML, Mc Whorter WP (1994) Colorectal cancers of rare histologic types compared with adenocarcinomas. Dis Colon Rectum 37(12): 1277-1280.

70. Makinen MJ, George SMC, Jernvall P, Makela J, Vihko P, et al. (2001) Colorectal carcinoma associated with serrated adenoma-prevalence, histological features, and prognosis. J Pathol 193(3): 286-294.

71. Oh K, Redston M, Odze RD (2005) Support for hMLH1 and MGMT silencing as a mechanism of tumorigenesis in the hyperplastic-adenomacarcinoma (serrated) carcinogenic pathway in the colon. Hum Pathol 36(1): 101-111.

72. Tsai CJ, Lu DK (1995) Small colorectal polyps: histopathology and clinical significance. Am J Gastroenterol 90(6): 988-994.

73. Rubin CE, Bronner MP (2003) Endoscopic mucosal biopsy: a memorial to Rodger C. Haggitt, M.D. In: Yamada T, Alpers D, Kaplowitz N, et al, (Eds.). Textbook of gastroenterology. (4th Edn.). Lippincott Williams \& Wilkins, Philadelphia, USA, pp. 2893-2946.

74. Schlemper RJ, Riddell RH, Kato Y, Borchard F, Cooper HS, et al. (2000) The Vienna classification of gastrointestinal epithelial neoplasia. Gut 47(2): 251-255.

75. Chapuis PH, Dent OF, Fisher R, Newland RC, Pheils MT, et al. (1985) A multivariate analysis of clinical and pathological variables in prognosis after resection of large bowel cancer. Br J Surg 72(9): 698-702.

76. D’Eredita G, Serio G, Neri V, Polizzi RA, Barberio G, et al. (1996) A survival regression analysis of prognostic factors in colorectal cancer. Aust N Z J Surg 66(7): 445-451.

77. Frank R, Saclarides T, Leurgans S, Speziale NJ, Drab EA, et al. (1995) Tumor angiogenesis as a predictor of recurrence and survival in patients with node-negative colon cancer. Ann Surg 222(6): 695-659.

78. Griffin M, Bergstralh E, Coffey RJ, Beart RW, Melton LJ (1987) Predictors of survival after curative resection of carcinoma of the colon and rectum. Cancer 60(9): 2318-2324.

79. Mulcahy HE, Skelly MM, Husain A, O’Donoghue DP (1996) Longterm outcome following curative surgery for malignant large bowel obstruction. Br J Surg 83(1): 46-50.

80. Newland R, Dent O, Lyttle MN, Chapuis PH, Bokey EL (1994) Pathologic determinants of survival associated with colorectal cancer with lymph node metastases. A multivariate analysis of 579 patients. Cancer 73(8): 2076-2082 
81. Roncucci L, Fante R, Losi L, Di Gregorio C, Micheli A, et al. (1996) Survival for colon and rectal cancer in a population-based cancer registry. Eur J Cancer 32A(2): 295-302.

82. Takebayashi Y, Akiyama S, Yamada K, Akiba S, Aikou T (1996) Angiogenesis as an unfavorable prognostic factor in human colorectal carcinoma. Cancer 78(2): 226-231.

83. Crucitti F, Sofo L, Doglietto GB, Bellantone R, Ratto C, et al. (1991) Prognostic factors in colorectal cancer: current status and new trends. J Surg Oncol 2: 76-82.

84. Deans G, Heatley M, Anderson N, Patterson CC, Rowlands BJ, et al. (1994) Jass' classif classification revisited. J Am Coll Surg 179(1): 11-17.

85. Deans GT, Patterson CC, Parks TG, Spence RA, Heatley M, et al. (1994) Colorectal carcinoma: importance of clinical and pathological factors in survival. Ann R Coll Surg Engl 76(1): 59-64.

86. Surbone A, Peccatori F, Pavlidis N (2008) Cancer and Pregnancy, Springer Berlin Heidelberg New York, USA, pp. 137-165.

87. Walsh C, Fazio VW (1998) Cancer of the colon, rectum, and anus during pregnancy: the surgeon's perspective. Gastroenterol Clin North Am 27(1): 257-267.

88. Harewood GC, Ahlquist DA (2000) Fecal occult blood testing for iron deficiency: a reappraisal. Dig Dis 18(2): 75-82.

89. Theologides A (1979) Cancer cachexia. Cancer 43(5 Suppl): 2004-2012.

90. Predescu D (2003) Surgical pathology in Chapter "Colic cancer", Ed. University" Carol Davila", București, p: 30-46

91. Macrae FA, St. John DJ (1982) Relationship between patterns of bleeding and Hemoccult sensitivity in patients with colorectal cancers or adenomas. Gastroenterology 82 (5 Pt 1): 891-898.

92. Helm JF, Sandler RS (1999) Colorectal cancer screening. Med Clin North Am 83(6): 39-44.

93. Mc Donnell WM, Ryan JA, Seeger DM, Elta GH (1989) Effect of iron on the guaiac reaction. Gastroenterology 96(1): 74-78.

94. Hardcastle JD, Armitage NC, Chamberlain J, Amar SS, James PD, et al (1986) Fecal occult blood screening for colorectal cancer in the general population: results of a controlled trial. Cancer 58(2): 397-403.

95. Simon JB (1998) Fecal occult blood testing: clinical value and limitations. Gastroenterologist 6(1): 66-78.

96. Winchester DP, Shull JH, Scanlon EF, Murrell JV, Smeltzer C, et al. (1980) A mass screening program for colorectal cancer using chemical testing for occult blood in the stool. Cancer 45(12): 2955-2958.

97. Baker WF Jr (2000) Iron deficiency in pregnancy, obstetrics, and gynecology. Hematology Oncology Clinics of North America 14(5): 10611077.

98. Rockey DC (1999) Occult Gastrointestinal Bleeding. N Engl J Med 341(1): 38-46.

99. Cappell MS, Goldberg ES (1992) The relationship between the clinical presentation and spread of colon cancer in 315 consecutive patients: a significant trend of earlier cancer detection from 1982 through 1988 at a university hospital. J Clin Gastroenterol 14(3): 227-235.

100. Ioannou GN, Rockey DC, Bryson CL, Weiss NS (2002) Iron deficiency and gastrointestinal malignancy: a population-based cohort study. Am J Med 113(4): 276-280.

101. Jonsson PE, Bengtsson G, Carlsson G, Jonson G, Tryding N (1984) Value of serum 5-nucleotidase, alkaline phosphatase and gammaglutamyl transferase for prediction of liver metastases preoperatively in colorectal cancer. Acta Chir Scand 150(5): 419-123.

102. Nagai Y, Beppu T, Sakamoto Y, Miyamoto Y, Hayashi H, et al. (2014) Carcinoembryonic Antigen Half-life Is an Early Predictor of Therapeutic Effects in Induction Chemotherapy for Liver Metastases from Colorectal Cancer. Anticancer Res 34(10): 5529-5535.
103. Moertel CG, O’Fallon JR, Go VLW, O'Connell MJ, Thynne GS (1986) The preoperative carcinoembryonic antigen test in the diagnosis, staging, and prognosis of colorectal cancer. Cancer 58(3): 603-610.

104. Fletcher RH (1986) Carcinoembryonic antigen. Ann Intern Med 104(1): 66-73

105. Hayes DF, Bast RC, Desch CE, Fritsche H Jr, Kemeny NE, et al. (1996) Tumor marker utility grading system: A framework to evaluate clinical utility of tumor markers. J Natl Cancer Inst 88(20): 1456-1466.

106. Macdonald JS (1999) Carcinoembryonic antigen screening: Pros and cons. Semin Oncol 26(5): 556-560.

107. Palmqvist R, Engaras B, Lindmark G, Hallmans G, Tavelin B, et al (2003) Prediagnostic levels of carcinoembryonic antigen and CA 242 in colorectal cancer: A matched casecontrol study. Dis Colon Rectum 46(11): 1538-1544

108. Duffy MJ, Van Dalen A, Haglund C, Hansson L, Klapdor R, et al. (2003) Clinical utility of biochemical markers in colorectal cancer: European Group on Tumour Markers (EGTM) guidelines. Eur J Cancer 39(6): 718-727.

109. Lamerz R, Ruider H (1976) Significance of CEA determinations in patients with cancer of the colon-rectum and the mammary gland in comparison to physiological states in connection with pregnancy. Bull Cancer 63(4): 575-586.

110. Locker GY, Hamilton S, Harris J, Jessup JM, Kemeny N, et al. (2006) ASCO 2006 Update of Recommendations for the Use of Tumor Markers in Gastrointestinal Cancer. Journal of Clinical Oncology 24(3): 53135327.

111. Arnaud JP, Koehl C, Adloff M (1980) Carcinoembryonic antigen (CEA) in diagnosis and prognosis of colorectal carcinoma. Dis Colon Rectum 23(3): 141-144.

112. Lennon T, Houghton J, Northover JM (1995) What is the value of clinical follow-up for colorectal cancer patients? The experience of the CRC/NIH CEA second-look trial-Proceedings of the Nottingham International Colorectal Cancer Symposium, Nottingham.

113. Northover J, Houghton J, Lennon T (1994) CEA to detect recurrence of colon cancer. JAMA 272(1): 31.

114. Koch M, Washer G, Gaedke H, McPherson TA (1982) Carcinoembryonic antigen: Usefullness as a postsurgical method in the detection of recurrence in Dukes stages B2 and C colorectal cancers. J Natl Cancer Inst 69(4): 813-815.

115. Pentheroudakis G, Pavlidis N, Castiglione M (2009) Cancer, fertility and pregnancy: ESMO Clinical Recommendations for diagnosis, treatment and follow-up. Annals of Oncology 20 (Suppl 4): iv178-iv181.

116. Nicklas A, Baker M (2000) Imaging strategies in pregnant cancer patients. Semin Oncol 27(6): 623-632.

117. Streffer C, Shore R, Konermann G, Meadows A, Uma Devi P, et al (2003) Biological effects after prenatal irradiation (embryo and fetus). A report of the International Commission on Radiological Protection. Ann ICRP 33(1-2): 5-206.

118. Rex DK, Rahmani EY, Haseman JH, Lemmel GT, Kaster S, et al. (1997) Relative sensitivity of colonoscopy and barium enema for detection of colorectal cancer in clinical practice. Gastroenterology 112(1): 17-23.

119. Blakeborough A, Sheridan MB, Chapman AH (1997) Complications of barium enema examinations: a survey of UK consultant radiologists 1992 to 1994. Clin Radiol 52(2): 142-148.

120. Cappell MS (1996) Gastrointestinal endoscopy in high risk patients. Dig Dis 14(4): 228-244.

121. Melmed AD (1991) Anesthesia principles and techniques in pregnancy. In: Cherr ST, Merkatz IR, eds. Complications of Pregnancy: Medical, Surgical, Gynecologic, Psychosocial, and Perinatal. (4th Edn.). Williams and Wilkins, Baltimore, Md, Maryland. 
122. Dark DS, Campbell DR, Wesselius LJ (1990) Arterial oxygen desaturation during gastrointestinal endoscopy. Am J Gastroenterol 85(10): 1317-1321.

123. Cappell MS, Colon VJ, Sidhom OA (1996) A study of eight medical centers of the safety and clinical efficacy of esophagogastroduodenoscopy in 83 pregnant females with follow-up of fetal in 83 pregnant females with follow-up of fetal outcome and with comparison control groups. Am J Gastroenterol 91(2): 348-354.

124. Cappell MS (2003) The fetal safety and clinical efficacy of gastrointestinal endoscopy during pregnancy. Gastroenterol Clin North Am 32(1): 123-179.

125. Cappell MS, Colon VJ, Sidhom OA (1996) A study at 10 medical centers of the safety and efficacy of 48 flexible sigmoidoscopies and 8 colonoscopies during pregnancy with follow-up of fetal outcome and with comparison to control groups. Dig Dis Sci 41(12): 2353-2361.

126. Cappell MS, Fiest TC (1995) A multicenter, multiyear, case-controlled study of the risk of colonic polyps in patients with gastric polyps. Are gastric adenomas a new indication for surveillance colonoscopy? J Clin Gastroenterol 21(3): 198-202.

127. Yaghoobi M, Koren G, Nulman I (2009) Challenges to diagnosing colorectal cancer during pregnancy. Can Fam Physician 55(9): 881885.

128. Lees WR (1993) Ultrasound of liver and spleen. In: Sutton D, Isherwood I, Forbes W, et al, eds. A Textbook of Radiology and Imaging. (5th Edn.). Churchill Livingstone, Edinburgh, NY, USA.

129. Nies C, Leppek R, Sitter H, Klotter HJ, Riera J, et al. (1996) Prospective evaluation of different diagnostic techniques for the detection of liver metastases at time of primary resection of colorectal carcinoma. Eur J Surg 162(10): 811-816.

130. Marone P, Petrulio F, De Bellis M, Battista Rossi G, Tempesta A (2000) Role of endoscopic ultrasonography in the staging of rectal cancer: a retrospective study of 63 patients. J Clin Gastroenterol 30(4): 420-424.

131. Gualdi GF, Casciani E, Guadalaxara A, D’Orta C, Polettini E, et al. (2000) Local staging of rectal cancer with transrectal ultrasound and endorectal magnetic resonance imaging: comparison with histologic findings. Dis Colon Rectum 43(3): 338-345.

132. Glaser F, Kuntz C, Schlag P, Herfarth C (1993) Endorectal ultrasound for control of preoperative radiotherapy of rectal cancer. Ann Surg 217(1): 64-71.

133. Herzog U, Von Flue M, Tondelli P, Schuppisser JP (1993) How accurate is endorectal ultrasound in the preoperative staging of rectal cancer? Dis Colon Rectum 36(2): 127-134.

134. Kim JC, Kim HC, Yu CS, Han KR, Kim JR, et al. (2006) Efficacy of 3-dimensional endorectal ultrasonography compared with conventional ultrasonography and computed tomography in preoperative rectal cancer staging. Am J Surg 192(1): 89-97.

135. Boyce GA, Sivak MV, Lavery IC, Church JM, Milsom J, et al. (1992) Endoscopic ultrasound in the preoperative staging of rectal cancer Gastrointest Endosc 38(4): 468-471.

136. Yamashita Y, Machi J, Shirouzu K, Morotomi T, Isomoto H, et al. (1998) Evaluation of endorectal ultrasound for the assessment of wall invasion of rectal cancer: Report of a case. Dis Colon Rectum 31(8): 617-623.

137. Beynon J (1989) An evaluation of the role of rectal endosonography in rectal cancer. Ann R Coll Surg Eng 71(2): 131-139.

138. Marone P, Petrulio F, De Bellis M, Battista Rossi G, Tempesta A (2000) Role of endoscopic ultrasonography in the staging of rectal cancer: a retrospective study of 63 patients. J Clin Gastroenterol 30(4): 420-424.

139. Badger SA, Devlin PB, Neilly PJ, Gilliland R (2007) Preoperative staging of rectal carcinoma by endorectal ultrasound: is there a learning curve? Int J Colorectal Dis 22(10): 1261-1268.

140. Spinelli P, Schiavo M, Meroni E, Di Felice G, Andreola S, et al. (1999) Results of EUS in detecting perirectal lymph node metastases of rectal cancer: The pathologist makes the difference. Gastrointest Endosc 49(6): 754-758.

141. Schwartz DA, Harewood GC, Wiersema MJ (2002) EUS for rectal disease. Gastrointestinal Endoscopy 56(1): 100-109.

142. Santiago RJ, Metz JM, Hahn S (2002) Chemoradiotherapy in the treatment of rectal cancer. Hematol Onco Clin N Am 16(4): 995-1014.

143. Catalano MF, Sivak MV Jr, Rice T, Gragg LA, Van Dam J (1994) Endosonographic features predictive of lymph node metastasis. Gastrointest Endosc 40(4): 442-446.

144. Bernini A, Deen KI, Madoff RD, Wong WD (1996) Preoperative adjuvant radiation with chemotherapy for rectal cancer: its impact on stage of disease and the role of endorectal ultrasound. Ann Surg Oncol 3(2): 131- 135 .

145. Thoeni RF (1997) Colorectal cancer. Radiologic staging. Radiol Clin North Am 35(2): 457-485.

146. Farouk R, Nelson H, Radice E, Mercill S, Gunderson L (1998) Accuracy of computed tomography in determining resectability for locally advanced primary or recurrent colorectal cancers. Am J Surg 175(4): 283-287.

147. Balthazar EJ, Megibow AJ, Hulnick D, Naidich DP (1988) Carcinoma of the colon: detection and preoperative staging by CT. AJR Am J Roentgenol 150(2): 301-306

148. Zerhouni EA, Rutter C, Hamilton SR, Balfe DM, Megibow AJ, et al. (1996) CT and MR imaging in the staging of colorectal carcinoma: report of the Radiology Diagnostic Oncology Group II. Radiology 200(2): 443-451.

149. Bhattacharjya S, Bhattacharjya T, Baber S, Tibballs JM, Watkinson AF, et al. (2004) Prospective study of contrast-enhanced computed tomography, computed tomography during arterioportography, and magnetic resonance imaging for staging colorectal liver metastases for liver resection. Br J Surg 91(10): 1361-1369.

150. Rotte KH, Kluhs L, Kleinau H, Kriedemann E (1989) Computed tomography and endosonography in the preoperative staging of rectal carcinoma. Eur J Radiol 9(3): 187-190.

151. Low G, Tho LM, Leen E, Wiebe E, Kakumanu S, et al. (2008) The role of imaging in the pre-operative staging and post-operative follow-up of rectal cancer. Surgeon 6(4): 222-231.

152. Wagner LK, Lester RG, Saldana LR (1985) Exposure of the pregnant patient to diagnostic radiations: a guide to medical management. Philadelphia; Lippincott pp. 19-223.

153. Berlin L (1996) Radiation exposure and the pregnant patient. AJR 167: 1377-1379.

154. Damilakis J, Prassopoulos P, Perisinakis K, Faflia C, Gourtsoyiannis N (1997) CT of the sacroiliac joints: Dosimetry and optimal settings for a high-resolution technique. Acta Radiol 38(5): 870-875.

155. Damilakis J, Perisinakis K, Voloudaki A, Gourtsoyiannis N (2000) Estimation of fetal radiation dose from computed tomography scanning in late pregnancy: depth-dose data from routine examinations. Investigative Radiology 35(9): 527-533.

156. Goldberg Stein S, Liu B, Hahn PF, Lee SI (2011) Body CT during pregnancy: utilization trends, examination indications, and fetal radiation doses. AJR 196(1):146-151.

157. Ratnapalan S, Bona N, Chandra K, Koran G (2004) Physicians' perceptions of teratogenic risk associated with radiography and CT during early pregnancy. AJR 182(5): 1107-1109.

158. Bentur Y (2001) Ionizing and nonionizing radiation in pregnancy. In: Koren G, ed. Maternal-fetal toxicology: a clinician's guide, (3rd Edn.). Marcel Dekker, New York, NY, USA, pp. 603-651.

159. Mole RH (1987) Irradiation of the embryo and foetus. Br J Radiol 60(709): 17-31

160. Doll R, Wakeford R (1997) Risk of childhood cancer from fetal irradiation. Br J Radiol 70: 130-139. 
161. Gilman EA, Kneale GW, Knox EG, Stewart AM (1988) Pregnancy X-rays and childhood cancers: effects of exposure age and radiation dose. J Radiol Prot 8: 3-8.

162. ACOG Committee on Obstetric Practice (2004) ACOG Committee Opinion. Number 299, September 2004. Guidelines for diagnostic imaging during pregnancy. Obstet Gynecol 104(3): 647-651.

163. Goldberg Stein SA, Liu B, Hahn PF, Lee SI (2012) Radiation dose management: part 2, estimating fetal radiation risk from CT during pregnancy. AJR 198: W352-356.

164. Morisetti A, Tirone P, Luzzani F, De Haen C (1994) Toxicologic safety assessment of iomeprol, a new x-ray contrast agent. Eur J Radiol 18(Suppl 1): S21-31.

165. Ralston WH, Robbins MS, James P (1989) Reproductive, developmental, and genetic toxicity of ioversol. Invest Radiol 1989; 24 (Suppl 1): S1622

166. Rodesch F, Camus M, Ermans AM, Dodion J, Delange F (1976) Adverse effects of amniofetography on fetal thyroid function. Am J Obstet Gynecol 126(6): 723-726.

167. Bona G, Zaffaroni M, Defilippi C, Gallina MR, Mostert M (1992) Effects of iopamidol on neonatal thyroid function. Eur J Radiol 14(1): 22-25.

168. Atwell TD, Lteif AN, Brown DL, Mc Cann M, Townsend JE, et al. (2008) Townsend and Andrew J. LeRoy Neonatal Thyroid Function After Administration of IV Iodinated Contrast Agent to 21 Pregnant Patients. Women's Imaging 191(1): 268-271.

169. Webb JA, Thomsen HS, Morcos SK (2005) Members of Contrast Media Safety Committee of European Society of Urogenital Radiology. The use of iodinated and gadolinium contrast media during pregnancy and lactation. Eur Radiol 15(6): 1234 -1240.

170. Morrin MM, Farrell RJ, Raptopoulos V, Mc Gee JB, Bleday R, et al. (2000) Role of virtual computed tomographic colonography in patients with colorectal cancers and obstructing colorectal lesions. Dis Colon Rectum 43(3): 303-311.

171. Halligan S, Altman DG, Taylor SA, Mallett S, Deeks JJ, et al. (2005) CT colonography in the detection of colorectal polyps and cancer: systematic review, meta-analysis, and proposed minimum data set for study level reporting. Radiology 237(3): 893-904.

172. Kim SH, Lee JM, Lee MW, Kim GH, Han JK, et al. (2008) Diagnostic accuracy of 3.0-Tesla rectal magnetic resonance imaging in preoperative local staging of primary rectal cancer. Invest Radiol 43(8): 587-593.

173. Tatli S, Mortele KJ, Breen EL, Bleday R, Silverman SG (2006) Local staging of rectal cancer using combined pelvic phased-array and endorectal coil MRI. J Magn Reson Imaging 23(4): 534-540.

174. Wong EM, Leung JL, Cheng CS, Lee JC, Li MK, et al. (2010) Effect of endorectal coils on staging of rectal cancers by magnetic resonance imaging. Hong Kong Med J 16(6): 421-426.

175. Chan TW, Kressel HY, Milestone B, Tomachefski J, Schnall M, et al. (1991) Rectal carcinoma: staging at MR imaging with endorectal surface coil. Work in progress. Radiology 181(2): 461-467.

176. Vogl TJ, Pegios W, Mack MG, Rausch M, Hintze H, et al. (1996) Radiological modalities in the staging of colorectal tumors: new perspectives for increasing accuracy. Recent Results Cancer Res 142: 103-120.

177. Zagoria RJ, Schlarb CA, Ott DJ, Bechtold RI, Wolfman NT, et al. (1997) Assessment of rectal tumor infiltration utilizing endorectal MR imaging and comparison with endoscopic rectal sonography. J Surg Oncol 64(4): 312-317.

178. Videhult P, Smedh K, Lundin P, Kraaz W (2007) Magnetic resonance imaging for preoperative staging of rectal cancer in clinical practice: high accuracy in predicting circumferential margin with clinical benefit. Colorectal Dis 9(5): 412-419.
179. Purkayastha S, Tekkis PP, Athanasiou T, Tilney HS, Darzi AW, et al. (2007) Diagnostic precision of magnetic resonance imaging for preoperative prediction of the circumferential margin involvement in patients with rectal cancer. Colorectal Dis 9(5): 402-411.

180. (2007) MERCURY Study Group, Extramural depth of tumor invasion at thin-section MR in patients with rectal cancer: results of the MERCURY study. Radiology 243(1): 132-139.

181. Kim SH, Lee JM, Park HS, Eun HW, Han JK, et al. (2009) Accuracy of MRI for predicting the circumferential resection margin, mesorectal fascia invasion, and tumor response to neoadjuvant hemoradiotherapy for locally advanced rectal cancer. J Magn Reson Imaging 29(5): 10931101.

182. Wieder HA, Rosenberg R, Lordick F, Geinitz H, Beer A, et al. (2007) Rectal cancer: MR imaging before neoadjuvant chemotherapy and radiation therapy for prediction of tumor-free circumferential resection margins and long-term survival. Radiology 243(3): 744-751.

183. Heinrichs WL, Fong P, Flannery M, Heinrichs SC, Crooks LE, et al. (1988) Midgestational exposure of pregnant BALB/c mice to magnetic resonance imaging. Mag Res Imag 6(3): 305-313.

184. Tyndall DA, Sulik KK (1991) Effects of magnetic resonance imaging on eye development in the C57BL/6J mouse. Teratology 43(3): 263-275.

185. Yip YP, Capriotti C, Talagala SL, Yip JW (1994) Effects of MR exposure at $1.5 \mathrm{~T}$ on early embryonic development of the chick. JMRI 4(5): 742748.

186. (1992) National Radiological Protection Board, Principles for the Protection of Patients and Volunteers During Clinical Magnetic Resonance Diagnostic Procedures. Ann N Y Acad Sci 649: 372-375.

187. Baker PN, Johnson IR, Harvey PR, Gowland PA, Mansfield P (1994) A three-year follow-up of children imaged in utero with echo-planar magnetic resonance. Am J Obstet Gynecol 170(1 Pt 1): 32-33.

188. Gover P, Hykin J, Gowland P, Wright J, Johnson I, et al. (1995) An assessment of the intrauterine sound intensity level during obstetric echo-planar magnetic resonance imaging. Br J Radiol 68(814): 10901094.

189. Marcos HB, Semelka RC, Worawattanakul S (1997) Normal placenta: gadolinium-enhanced dynamic MR imaging. Radiology 205(2): 493496.

190. Spencer JA, Tomlinson AJ, Weston MJ, Lloyd SN (2000) Early report: comparison of breath-hold MR excretory urography, Doppler ultrasound and isotope renography in evaluation of symptomatic hydronephrosis in pregnancy. Clin Radiol 55(6): 446-453.

191. Shellock FG (1991) Policies, guidelines, and recommendations for MR imaging safety and patient management. JMRI 1(1): 97-101.

192. Zanotti Fregonara P, Jan S, Taieb D, Cammilleri S, Trébossen R, et al. (2010) Absorbed 18F-FDG dose to the foetus during early pregnancy. J Nucl Med 51(5): 803-805

193. Takalkar AM, Khandelwal A, Lokitz S, Lilien DL, Stabin MG (2011) 18F-FDG PET in pregnancy and fetal radiation dose estimates. J Nucl Med 52(7): 1035-1040.

194. Hsieh TC MD, Wu YC, Sun SS, Chu LY, Yen KY, et al. (2012) FDG PETCT of a Late-term Pregnant Woman with Breast Cancer. Clin Nucl Med 37(5): 489-491.

195. Dunkelberg JC, Barakat J, Deutsch J (2005) Gastrointestinal, pancreatic, and hepatic cancer during pregnancy. Obstet Gynecol Clin North Am 32(4): 641-660.

196. Chan YM, Ngai SW, Lao TT (1999) Colon cancer in pregnancy: a case report. J Reprod Med 44(8): 733-736.

197. Krause H, Watt A (2003) Positive pregnancy test in a patient with colorectal carcinoma. Aust N Z J Obstet Gynaecol 43(3): 241-242. 
198. Braunstein GD, Vaitukaitis JL, Carbone PP, Rose GT (1973) Ectopic production of human chorionic gonadotrophin by neoplasms. Ann Intern Med 78(1): 39-45.

199. Campo E, Palacin A, Benasco C, Quesada E, Cardesa A (1987) Human chorionic gonadotropin in colorectal carcinoma: an immunohistochemical study. Cancer 59(9): 1611-1616.

200. Skinner JM, Whitehead R (1981) Tumor-associated antigens in polyps and carcinoma of the human large bowel. Cancer 47(6): 1241-1245.

201. Buckley CH, Fox H (1979) An immunohistochemical study of the significance of HCG secretion by large bowel adenocarcinomata. J Clin Pathol 32(4): 368-372.

202. Mason MH, Kovalcik PJ (1981) Ovarian metastases from colon carcinoma. J Surg Oncol 17(1): 33-38.

203. Tsukamoto N, Uchino H, Matsukuma K, Kamura T (1986) Carcinoma of the colon presenting as bilateral ovarian tumors during pregnancy. Gynecol Oncol 24(3): 386-391.

204. Pitluk H, Poticha SM (1983) Carcinoma of the colon and rectum in patients less than 40 years of age. Surg Gynecol Obstet 157(4): 335337.

205. Recalde M, Holyoke ED, Elias EG (1974) Carcinoma of the colon, rectum, and anal canal in young patients. Surg Gynecol Obstet 139(6): 909-913.

206. Herrera Ornelas L, Natarajan N, Tsukada Y, Prado Alcala E, Gutierrez Garcia CJ, et al. (1983) Adenocarcinoma of the colon masquerading as primary ovarian neoplasia: an analysis of ten cases. Dis Colon Rectum 26(6): $377-380$

207. Matsuyama T, Tsukamoto N, Matsukuma K, Kamura T, Kaku T, et al. (1989) Malignant ovarian tumors associated with pregnancy: report of six cases. Int J Gynaecol Obstet 28(1): 61-66.

208. Cappell MS (2003) Colon cancer during pregnancy. Gastroenterol Clin North Am 32(1): 341-383.

209. Nicholas A (2002) Pavlidis Coexistence of Pregnancy and Malignancy. Oncologist 7(4): 279-287.

210. Hugh RK Barber (2005) Malignant disease in pregnancy. Journal of Perinatal Medicine 29(2): 97-111.

211. Woods JB, Martin JN, Ingram FH, Odom CD, Scott Conner CE, et al. (1992) Pregnancy complicated by carcinoma of the colon above the rectum. Am J Perinatol 9(2): 102-110.

212. Hill JA, Kassam SH, Talledo OE (1984) Colonic cancer in pregnancy. South Med J 77(3): 375-378.

213. Arbman G, Nilsson E, Storgren Fordell V, Sjödahl R (1996) A short diagnostic delay is more important for rectal cancer than for colonic cancer. Eur J Surg 162(11): 899-904.

214. Saunders P, Milton PJ (1973) Laparotomy during pregnancy: an assessment of diagnostic accuracy and fetal wastage. BMJ 3(5872): 165-167.

215. Skilling JS (1998) Colorectal cancer complicating pregnancy. Obstet Gynecol Clin North Am 25(2): 417-421.

ISSN: 2574-1241

DOI: 10.26717/BJSTR.2020.27.004553

Predescu Dragos. Biomed J Sci \& Tech Res

(c) (i) This work is licensed under Creative

Submission Link: https://biomedres.us/submit-manuscript.php
216. Mazze RI, Kallen B (1989) Reproductive outcome after anesthesia and operation during pregnancy: a registry study of 5,405 cases. Am J Obstet Gynecol 161(5): 1178-1185.

217. Curet MJ, Allen D, Josloff RK, Pitcher DE, Curet LB, et al. (1996) Laparoscopy during pregnancy. Arch Surg 131(5): 546-551.

218. Rizzo AG (2003) Laparoscopic surgery in pregnancy: long-term follow up. J Laparoendosc Adv Surg Tech A 13(1): 11-15.

219. Lemaire BM, Van Erp WF (1997) Laparoscopic surgery during pregnancy. Surg Endosc 11(1): 15-18.

220. (1994) Management of the woman with threatened birth of an infant of extremely low gestational age. Fetus and Newborn Committee, Canadian Paediatric Society, Maternal-Fetal Medicine Committee, Society of Obstetricians and Gynaecologists of Canada. CMAJ 151(5): 547-553.

221. Malangoni MA (2003) Gastrointestinal surgery and pregnancy. Gastroenterol Clin North Am 32(1): 181-200.

222. Briggs GG, Freeman RK, Yaffe SJ (2002) Folic acid. Drugs in pregnancy and lactation: a reference guide to fetal and neonatal risk. Lippincott Williams Wilkins, Philadelphia, USA, pp. 583-597.

223. Minter A, Malik R, Ledbetter L, Winokur TS, Hawn MT, et al. (2005) Colon Cancer in Pregnancy. Cancer Control 12(3): 196-202.

224. Doll DC, Ringenberg QS, Yarbro JW (1989) Antineoplastic agents and pregnancy. Semin Oncol 16(5): 337-346.

225. Ellis GK, Barlow WE, Gralow JR, Hortobagyi GN, Russell CA, et al. (2011) Phase III comparison of standard doxorubicin and cyclophosphamide versus weekly doxorubicin and daily oral cyclophosphamide plus granulocyte colony-stimulating factor as neoadjuvant therapy for inflammatory and locally advanced breast cancer: SWOG 0012. J Clin Oncol 29(8): 1014-1021.

226. Sparano JA, Wang M, Martino S, Jones V, Perez EA, et al. (2008) Weekly paclitaxel in the adjuvant treatment of breast cancer. N Engl J Med 358(16): 1663-1671.

227. Aytac E, Ozuner G, Isik O, Gorgun E, Stocchi L (2016) Management of colorectal neoplasia during pregnancy and in the postpartum period. World journal of gastrointestinal oncology 8(7): 550-554.

228. Kal HB, Struikmans H (2005) Radiotherapy during pregnancy: fact and fiction. Lancet Oncol 6(5): 328-333.

229. Spanheimer PM, Graham MM, Sugg SL, Scott Conner CE, Weigel RJ (2009) Measurement of uterine radiation exposure from lymphoscintigraphy indicates safety of sentinel lymph node biopsy during pregnancy. Ann Surg Oncol 16(5): 1143-1147.

230. Jeppesen JB, Osterlind K (2011) Successful twin pregnancy outcome after in utero exposure to FOLFOX for metastatic colon cancer: a case report and review of the literature. Clin Colorectal Cancer 10(4): 348352.

231. Morice P, Uzan C, Uzan S (2012) Cancer in pregnancy: a challenging conflict of interest. Lancet 379: 495-496.

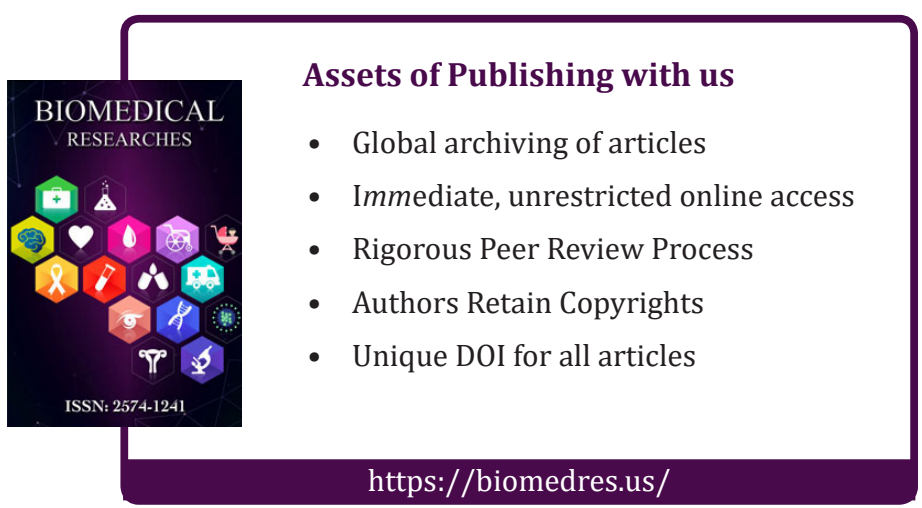

https://biomedres.us/ 